ISSN 2311-8733 (Online)

ISSN 2073-1477 (Print)

ФИНАНСОВОЕ СОСТОЯНИЕ СЕЛЬСКОХОЗЯЙСТВЕННЫХ ПРЕДПРИЯТИЙ: ПРОБЛЕМЫ, ТЕНДЕНЦИИ, ПЕРСПЕКТИВЫ (РЕГИОНАЛЬНЫЙ АСПЕКТ)

\author{
Ирина Викторовна ШАРИКОВА ${ }^{\mathrm{a}, \bullet}$, Артем Викторович ШАРИКОВ \\ Татьяна Владимировна ГОВОРУНОВА', Наталья Петровна ФЕФЕЛОВА ${ }^{\mathrm{d}}$
}

${ }^{\text {a }}$ кандидат экономических наук, заведующая кафедрой бухгалтерского учета, анализа и аудита,

Саратовский государственный аграрный университет им. Н.И. Вавилова, Саратов, Российская Федерация ivcharikova@yandex.ru

${ }^{\mathrm{b}}$ кандидат экономических наук, доцент кафедры бухгалтерского учета, анализа и аудита, Саратовский государственный аграрный университет им. Н.И. Вавилова, Саратов, Российская Федерация ooo_br@mail.ru

c кандидат экономических наук, доцент кафедры бухгалтерского учета, анализа и аудита,

Саратовский государственный аграрный университет им. Н.И. Вавилова, Саратов, Российская Федерация govorunovatv@mail.ru

${ }^{\mathrm{d}}$ кандидат экономических наук, доцент кафедры бухгалтерского учета, анализа и аудита, Саратовский государственный аграрный университет им. Н.И. Вавилова, Саратов, Российская Федерация fefelovanp@mail.ru

• Ответственный автор

\section{История статьи:}

Принята 07.07.2016

Принята в доработанном виде 25.07.2016

Одобрена 09.08.2016

Доступна онлайн 15.05.2017

УДК 338.1

JEL: D22, G17, P47, R15, R51 https://doi.org/10.24891/re.15.5.869

\section{Ключевые слова:}

платежеспособность, текущие обязательства, устойчивость, золотое правило, группировка

\begin{abstract}
Аннотация
Предмет. Проблема низкой финансовой устойчивости предприятий аграрного сектора играет доминирующую роль в экономике России не только как «экономическая болезнь», но и как результат поведения предприятий в течение всей производственно-хозяйственной деятельности. Финансовое состояние - это многомерное явление, которое представляет собой результат влияния большого количества факторов, не только определяющих структуру капитала, его движение, но и конкурентоспособность предприятия, умение строить деловые отношения с партнерами.

Цели. Комплексное авторское исследование проблемы финансового состояния предприятий аграрного сектора. Мониторинг платежеспособности сельскохозяйственных предприятий, оценка их роли в обеспечении финансовой устойчивости в регионе.

Методология. На основе экономико-статистических методов дается оценка динамики показателей, характеризующих финансовое состояние сельскохозяйственных предприятий области, проводится их группировка по степени платежеспособности по текущим обязательствам, обосновываются параметры регрессионной модели зависимости платежеспособности от основных факторов.

Результаты. Определено, что на территории Саратовской области есть административные районы, имеющие кризисное или неустойчивое финансовое состояние. Выявлено, что в течение анализируемого периода четко прослеживаются позитивные изменения в составе и структуре баланса (рост собственного и долгосрочного капиталов, внеоборотных и собственных оборотных активов при одновременном сокращении краткосрочных обязательств), что позволило укрепить финансовую устойчивость аграрных предприятий, переведя финансовое состояние из кризисного в разряд неустойчивого. Проведена оценка показателей вариации и типа распределения платежеспособности сельскохозяйственных предприятий одного из районов области, обоснована и предложена регрессионная модель зависимости степени платежеспособности от основных производственных факторов.

Выводы. Большинство (70\%) предприятий района относятся к первой группе платежеспособности и могут отвечать по своим текущим обязательствам в течение установленного срока, то есть трех месяцев. Однако степень их усилий в обеспечении нормативных сроков платежей различна.
\end{abstract}

Государственная программа развития сельского хозяйства и регулирования рынков сельскохозяйственной продукции, сырья и продовольствия на 2013-2020 гг. (далее Программа) в качестве приоритетов первого уровня в экономической сфере определяет повышение доходов сельскохозяйственных товаропроизводителей, а среди общего

$\begin{array}{lcr}\text { многообразия } & \text { целей } & \text { Программа выделяет } \\ \text { «повышение } & \text { финансовой }\end{array}$ товаропроизводителей агропромышленного комплекса» ${ }^{1}$.

\footnotetext{
${ }^{1}$ Государственная программа развития сельского хозяйства и регулирования рынков сельскохозяйственной продукции, сырья и продовольствия на 2013-2020 годы: постановление Правительства Российской Федерации от 14.07.2012 № 717.
}

И.В. Шарикова и др. / Региональная экономика: теория и практика, 2017, т. 15, вып. 5, стр. 869-880 
Мультипликативный эффект реализации Программы за 2012-2014 гг. проявился в повышении эффективности «собственного производства», росте выручки и четко обозначившейся марже «для дальнейшего ведения сельского хозяйства...»². Это для аграрного сектора экономики, стремительно теряющего свои конкурентные позиции в предшествующие экономическим санкциям годы, шанс увеличить производство и вернуть рынок «национальным производителям». Достижение поставленной цели в экономической сфере призвано обеспечить решение ряда задач в сфере социальной, важнейшей из которых, на наш взгляд, является «сохранение трудовых ресурсов». Однако в сложившихся условиях решить ее невозможно без обеспечения устойчивого развития сельских территорий, создания условий для обеспечения экономической и физической доступности питания на основе рациональных норм потребления пищевых продуктов. Современные подходы обеспечения устойчивого развития достаточно подробно рассмотрены в работах В. Коновалова, Т. Коноваловой [1], И. Романенко, С. Сиптиц [2], Н. Фефеловой, Т. Говоруновой и др. [3]. Решение данных вопросов будет способствовать достижению более глобальных целей Программы: обеспечению продовольственной независимости и территориальной целостности страны. Поэтому вопросы финансовой устойчивости, укрепления финансового состояния становятся основными для любого предприятия, осуществляющего коммерческую деятельность. Уровень применяемых технологий, расширение или сокращение производства, поиск новых рынков сбыта определяется применяемой стратегией в управлении финансами. Мониторинг показателей, характеризующих финансовое состояние организации, и методика его проведения детально рассмотрены в трудах Т.В. Воронченко [4], Д.В. Манушина [5], О.Ю. Патласова и Н.В. Васиной [6], Л.Г. Симоненко [7], B.Н. Бариленко и др. [8], что позволяет своевременно отслеживать как позитивные, так и негативные изменения в производственной, финансовой, маркетинговой, инвестиционной деятельности, оперативно реагировать на происходящие изменения.

Анализ финансового состояния мы проводили в сельскохозяйственных предприятиях одного из аграрных регионов - в Саратовской области. Для

\footnotetext{
${ }^{2}$ Национальный доклад «О ходе и результатах реализации в 2014 году Государственной программы развития сельского хозяйства и регулирования рынков сельскохозяйственной продукции, сырья и продовольствия на 2013-2020 годы»: распоряжение Правительства Российской Федерации от 06.05.2015 № 803-р.
}

исследования был выбран Базарно-Карабулакский район с достаточно типичными для значительной части нашей страны объективными условиями ведения аграрного производства. В настоящее время в районе функционируют 17 сельскохозяйственных предприятий различных организационно-правовых форм, стабильная материально-производственная база которых наряду с эффективным менеджментом обеспечивает тенденцию роста положительного финансового результата.

Индикатором оценки финансового состояния предприятия выступает бухгалтерский баланс. Именно анализ баланса позволяет обозначить возникающие проблемы, выявить намечающиеся тенденции, о чем свидетельствуют труды А.Н. Бобрышева [9], А.С. Абросимовой и др. [10].

В анализируемых предприятиях прослеживается увеличение валюты баланса, составившее за последние три года $15 \%$ при уровне инфляции в области за этот период в $18 \%$ (базисный индекс). Темпы роста выручки составляли $39,6 \%$.

Баланс анализируемых предприятий характеризуется сложной структурой имущества:

- на внеоборотные активы приходятся 56\% (из них $47 \%$ - основные средства);

- оборотные активы составляют 44\%, для них характерна большая доля запасов (39\%) при незначительном (менее 2,5\%) удельном весе денежных средств, что ухудшает ликвидность текущих активов;

- на $77-81 \%$ имущество формируется за счет собственного капитала, из которого $46-54 \%$ составляет нераспределенная прибыль и $28-25 \%$ - переоценка внеоборотных активов.

Применяемая модель финансирования имущества, оцениваемая экономистами, в частности В.В. Ковалевым ${ }^{3}$, как агрессивная, имеет ярко выраженные проблемы с ликвидностью (дефицит свободных денежных средств особенно в напряженные периоды деятельности), обладает высокой степенью риска потерь от приостановки деятельности или неполучения возможных доходов при возрастании спроса на продукцию в пиковые периоды (рuс. 1).

В анализируемых предприятиях отмечается прирост собственного капитала на $21,4 \%$ за счет увеличения нераспределенной прибыли на $35,7 \%$

${ }^{3}$ Ковалев В.В. Финансовый менеджмент: теория и практика. М.: Проспект, 2013. 1094 с. 
и отчислений на формирование резервного капитала на $11,8 \%$. Четко прослеживается прирост инвестиционного или долгосрочного капитала на $34,1 \%$ при одновременном сокращении текущих обязательств на 19,3\%. Данные изменения следует расценивать как позитивные. При этом уменьшение краткосрочных обязательств происходит не только по статье «Заемные средства» (на 18,6\%), но и по статье «Кредиторская задолженность» (на 6,5\%), что свидетельствует об улучшении расчетов с контрагентами.

Подводя итог анализа динамики и структуры баланса, следует признать, что сельскохозяйственные предприятия БазарноКарабулакского района придерживаются основных правил формирования его горизонтальной структуры, суть которых сводится к согласованности сроков вложения финансовых ресурсов в реальные или финансовые активы со сроками их мобилизации. Современные подходы к теории и практике формирования и использования финансовых ресурсов изложены в трудах С.Л. Жуковской, М.С. Оборина [11], С.Л. Комельчик [12], С.M. Козыревой и В.В. Колчериной [13], Д.В. Манушина [14]. При этом соотношение долгосрочных активов с долгосрочными пассивами (меньше либо равно 1) и краткосрочных активов с краткосрочным капиталом (больше либо равно 1) соответствует нормативу (рис. 2).

Однако сама по себе структура имущества и даже ее анализ в динамике позволяют оценить лишь состав активов, объем долгов и возможность их покрытия, но не определяют степень эффективности произведенных вложений. Ответ на этот вопрос можно получить, анализируя показатели финансовой устойчивости путем сравнения имеющихся объемов запасов c источниками их формирования. При этом используют три основных показателя, характеризующих излишек или недостаток собственных оборотных средств, собственных и долгосрочных средств, общей величины основных источников формирования запасов. Трехкомпонентный показатель, получаемый в результате сальдовой оценки суммы указанных источников и объема запасов (больше нуля оценивается как 1 , меньше - как 0) составил в 2012 г. $-0 ; 0 ; 0$, в 2013 и 2014 г. - по 0; 0; 1. Эти данные свидетельствуют о кризисном финансовом состоянии анализируемой совокупности предприятий в 2012 г. Однако отмеченные изменения в составе и структуре баланса (рост собственного, внеоборотных и собственных оборотных активов при одновременном сокращении краткосрочных обязательств) позволил укрепить финансовую устойчивость аграрных предприятий, переведя финансовое состояние в разряд неустойчивого.

Проведенный анализ методических подходов к оценке финансового состояния предприятий, изложенный в работах Н.В. Волосевич [15], Н.К. Швецовой [16] и подтвержденный нашими собственными исследованиями [17] показал, что степень платежеспособности предприятий по текущим обязательствам является весьма важным показателем. Ведь при признании должника банкротом учитывается, как быстро предприятие может отвечать по своим обязательствам. Мы рассчитали данный показатель, характеризующий продолжительность периода, в течение которого предприятия смогут погасить свои долги, и определили степень его колеблемости в разрезе изучаемой совокупности. Исследования показали, что степень платежеспособности имеет значительные колебания по предприятиям, причиной которых несмотря на единые территориальные и экономические условия являются различия в специализации предприятий, умении осуществлять менеджмент, различный уровень мастерства и квалификации специалистов предприятий и др. При этом разброс в значениях составлял от менее $1 \mathrm{мес.} \mathrm{(ООО} \mathrm{«Ивановское»)} \mathrm{до}$ 58 мес. (ООО «Кудашевский конезавод»). Для оценки степени колеблемости данного показателя мы использовали методы описательной статистики, выполненные в Microsoft Excel (табл. 1).

Данные расчеты позволяют определить в динамике наиболее благоприятный год в плане платежеспособности аграрных предприятий. Таким годом является 2013 г., когда наблюдался минимальный уровень коэффициента вариации, дисперсии, среднего квадратического отклонения, эксцесса и асимметричности. Два последних показателя характеризуют тип распределения. По сравнению с другими годами в 2013 г. распределение предприятий по степени платежеспособности было максимально приближено к нормальному типу распределения. В то же время среднее значение платежеспособности было меньше в 2014 г., а значение медианы свидетельствовало о том, что в 2014 г. более половины предприятий имели сроки платежеспособности менее 1,958 мес. (в 2013 г. - 2,016 мес., в 2012 г. - 1,967 мес.). Кроме того, распределение предприятий в 2014 г. было островершинным и характеризовалось максимальной правосторонней асимметрией (puc. 3). 
Для оценки типа платежеспособности анализируемых предприятий мы провели их разноску по группам платежеспособности. В результате было выявлено, что девять предприятий Базарно-Карабулакского района на протяжении ряда лет могут ответить по своим обязательствам в сроки, не превышающие 3 мес. На протяжении всего анализируемого периода они стабильно относятся к первой группе платежеспособности.

К таким предприятия относятся (табл. 2):

- ООО «Ивановское»;

- СПК СХА «Дружба»;

- ООО «Роща»;

- ООО «Долина»;

- ООО «Колосок»;

- СХПК СХА «Старожуковская»;

- СХПК СХА «Искра»;

- СХПК СХА «Нееловская»;

- ООО «Ивановское».

При этом ООО «Снежное» только на протяжении 2012-2013 г. смогло обеспечить высокий уровень платежеспособности. В 2014 г. сроки оплаты по текущим обязательствам у этого предприятия превысили 3 мес., и оно автоматически перешло во вторую группу.

Для ООО «Гусихинское» сложным оказался 2013 г. В результате этого оно из первой группы переместилось во вторую, но по итогам работы 2014 г. восстановило свои позиции. СПК СХА «Алексеевская» и СХПК СХА «Содомская» в 2012 г. относились к неплатежеспособным предприятиям первой категории (срок погашения краткосрочных обязательств составлял от 3 до 12 мес.). Но начиная с 2013 г. они прочно занимают позиции предприятий первой группы, к которым в 2014 г. присоединяется и СПК СХА «Вязовская». ООО «Агро-Нива» на протяжении всех трех лет стабильно испытывает определенные сложности в платежеспособности, однако сроки оплаты краткосрочных обязательств ни разу не превышали 12 мес., что соответствует второй группе.

В третьей группе неплатежеспособных предприятий в 2012-2013 гг. находились три предприятия: МУП «БК птицефабрика», ЗАО ПЗ «Липовское», ООО «Кудашевский КЗ», у которых сроки оплаты по краткосрочным долгам занимали более года. В 2014 г. у первых двух предприятий финансовое состояние улучшается (как результат планомерной работы) и они меняют категорию неплатежеспособности со второй на первую, переходя во вторую группу. Таким образом, на конец 2014 г. в третьей группе неплатежеспособных предприятий остается один Кудашевский конезавод.

Чтобы выяснить причины, определяющие уровень платежеспособности аграрных предприятий, мы применили метод группировок и корреляционнорегрессионного анализа для выявления и оценки силы связи между признаками, а также определения теоретической формы связи, описываемой алгебраическим уравнением. Современные подходы к применению статистических методов в оценке финансового состояния предприятий агропромышленного комплекса широко представлены в работах А.А. Алексеева [18], Т.В. Высоцкой [19], В.М. Корнева [20]. В качестве результативного признака мы выбрали степень платежеспособности предприятий по текущим обязательствам (обозначим его Y), а отобранные нами факторные признаки, представим в табл. 3. Вначале мы провели группировку предприятий по уровню платежеспособности по текущим обязательствам. При этом деление совокупности на группы и границы группы были сформированы в соответствии с табл. 2.

Данная группировка не устанавливает наличия жесткой (функциональной) связи между всеми отобранными признаками. Она прослеживается только по трем из четырех отобранных факторов, поэтому можно утверждать, что с увеличением окупаемости затрат и уровня государственной поддержки при одновременном снижении доли заемного капитала и оптимизации структуры имущества сроки платежеспособности предприятий по текущим обязательствам сокращаются.

Далее, используя метод корреляционнорегрессионного анализа, мы провели оценку степени влияния отобранных факторов на результативный показатель. Все вычисления были реализованы при использовании прикладных программ Microsoft Excel. Вначале нами изучалось влияние каждого из отобранных факторов на результат. Исследование показало, что наиболее сильное влияние на степень платежеспособности по текущим обязательствам оказывает удельный вес заемного капитала и окупаемость затрат. Коэффициенты парной корреляции между данными факторами и результативным признаком 
соответственно равны 0,796 и $-0,702$, что свидетельствует о наличии высокой (прямой в первом и обратной во втором случае) связи. Влияние удельного веса оборотного капитала и уровня государственной поддержки на степень платежеспособности можно оценить как заметную: коэффициенты парной корреляции соответственно равны 0,573 и $-0,543$. При этом снова в первом случае связь прямая, во втором обратная.

Совместное влияние всех отобранных факторов, а также синергетический эффект от их взаимодействия характеризует коэффициент множественной корреляции, равный 0,889 $(R=0,889)$, что свидетельствует о наличии достаточно сильной связи между анализируемыми признаками. Квадрат данного коэффициента называется коэффициентом детерминации $\left(R^{2}=0,8892=0,791\right)$. Он показывает степень изменения результативного признака под влиянием изучаемых факторов. Так, в анализируемых предприятиях Базарно-Карабулакского района изменения степени платежеспособности по текущим обязательствам на $79,1 \%$ зависят от отобранных факторов. На влияние оставшихся факторов приходится всего лишь 20,9\%.

В рамках регрессионного анализа мы определяли форму связи между данными признаками и после проведенного исследования получили уравнение, описывающее выявленную зависимость:

$$
Y_{x}=1,998-0,104 \times 1+1,111 \times 2+2,08 \times 3-0,055 \times 4 .
$$

Коэффициенты при переменных - коэффициенты чистой регрессии показывают как меняется результативный признак с увеличением факторного признака на единицу. Так, увеличение окупаемости затрат на один порядок и уровня государственной поддержки на 1 тыс. руб. ведет к улучшению степени платежеспособности на 0,104 и 0,055 пункта соответственно. В тоже время рост удельного веса заемного и оборотного капитала в валюте баланса на $1 \%$ ухудшает данный показатель соответственно на 1,111 и 2,08 пункта. Необходимо отметить, что все полученные коэффициенты регрессии и свободный член уравнения являются достоверными и значимыми, так как превышают величину их стандартной ошибки, что подтверждает закономерный характер выявленной зависимости.

В итоге проведенного анализа нами были получены теоретические или нормативные (потенциально возможные) значения степени платежеспособности аграрных предприятий в фактических условиях их функционирования (табл. 4).

Таким образом, девять из семнадцати сельскохозяйственных предприятий района исчерпывающе (в полную меру) используют имеющиеся у них ресурсы, обеспечивая тем самым превышение фактических значений анализируемого показателя над нормативными. К этой группе относятся и два неплатежеспособных предприятия первой категории: ЗАО ПЗ «Липовское», которое ценой определенных усилий смогло перейти из третьей группы во вторую, улучшив тем самым свою финансовую устойчивость, а также ООО «АгроНива», сумевшее значительно сократить сроки платежей по текущим обязательствам в сравнении в предыдущими годами и в сравнении с нормативом (табл. 2).

Из восьми предприятий с неиспользованными в полной мере резервами по оптимизации платежеспособности необходимо выделить Кудашевский конный завод и БазарноКарабулакскую птицефабрику. В этих предприятиях есть серьезные проблемы и со структурой капитала, и со структурой имущества. Чрезвычайно высок удельный вес заемного капитала (66,8 и $99,7 \%$ соответственно), что вызывает большие суммы ежемесячных платежей. В то же время на птицефабрике остро ощутим недостаток оборотных средств вообще (всего лишь $22,3 \%$ ), и денежных в частности. А на конном заводе все имущество состоит из оборотного капитала $(100 \%)$, однако дефицит денежных средств налицо.

Таким образом, подводя итог анализу финансового состояния сельскохозяйственных предприятий, следует признать, что они прилагают значительные усилия в наращивании экономического потенциала, стремятся соблюдать правила и законы рыночной экономики, способны обеспечить необходимые условия для устойчивого развития сельских территорий. Однако их усилия по укреплению экономического потенциала поглощаются темпами существующей инфляции. Применяемая модель финансирования хозяйственной деятельности, оцениваемая многими экономистами как «весьма рискованная», вызывает проблемы с ликвидностью и платежеспособностью в результате органически присущего ей дефицита свободных денежных средств в напряженные периоды деятельности, составляющие в предприятиях аграрного сектора более 5 мес. 


\section{Таблица 1}

Показатели вариации степени платежеспособности сельскохозяйственных предприятий Базарно-Карабулакского района в 2012-2014 гг.

Table 1

Variations of the degree of solvency of agricultural enterprises of the Bazarno-Karabulakskii district in 2012-2014

\begin{tabular}{|c|c|c|c|}
\hline Показатель & 2012 & 2013 & 2014 \\
\hline Среднее & 4,98 & 3,128 & 2,877 \\
\hline Стандартная ошибка & 3,728 & 1,413 & 1,467 \\
\hline Медиана & 1,967 & 2,016 & 1,958 \\
\hline Стандартное отклонение & 15,371 & 5,826 & 6,047 \\
\hline Дисперсия выборки & 236,283 & 33,941 & 36,572 \\
\hline Коэффициент вариации & 1,812 & 1,221 & 1,582 \\
\hline Эксцесс & 6,653 & 1,46 & 9,952 \\
\hline Асимметричность & 2,564 & 1,54 & 3,033 \\
\hline Интервал (размах вариации) & 57,994 & 19,579 & 24,865 \\
\hline Минимум & 0 & 0 & 0 \\
\hline Максимум & 57,994 & 19,579 & 24,865 \\
\hline Сумма & 144,251 & 81,142 & 64,997 \\
\hline Счет & 17 & 17 & 17 \\
\hline Уровень надежности (95\%) & 7,903 & 2,995 & 3,109 \\
\hline
\end{tabular}

Источник: рассчитано на основе данных годового баланса

Source: Calculation based on annual balance sheet data

\section{Таблица 2}

Распределение сельскохозяйственных предприятий Базарно-Карабулакского района по степени платежеспособности по текущим обязательствам в 2012-2014 гг.

\section{Table 2}

Distribution of agricultural enterprises of the Bazarno-Karabulakskii district according to the degree of solvency by current liabilities in 2012-2014

\begin{tabular}{|c|c|c|c|}
\hline $\begin{array}{c}\text { Группы предприятий } \\
\text { по степени } \\
\text { платежеспособности }\end{array}$ & 2012 & 2013 & 2014 \\
\hline $\begin{array}{l}\text { 1. Платежеспособные } \\
\text { организации (до 3-х мес.) }\end{array}$ & $\begin{array}{l}\text { ООО «Ивановское», } \\
\text { СПК СХА «Дружба», } \\
\text { ООО «Роща», } \\
\text { ООО «Долина», } \\
\text { ООО «Колосок», СХПК } \\
\text { СХА «Старожуковская», } \\
\text { СХПК СХА « Искра», } \\
\text { СХПК СХА «Нееловская», } \\
\text { ООО «Снежное», } \\
\text { ООО «Гусихинское» }\end{array}$ & $\begin{array}{l}\text { ООО «Ивановское», } \\
\text { СПК СХА «Дружба», } \\
\text { ООО «Роща», } \\
\text { ООО «Долина», } \\
\text { ООО «Колосок», } \\
\text { СХПК СХА } \\
\text { «Старожуковская», } \\
\text { СХПК СХА «Искра», } \\
\text { СХПК СХА «Нееловская», } \\
\text { ООО «Снежное», } \\
\text { СПК СХА «Алексеевская», } \\
\text { СХПК СХА «Содомская» }\end{array}$ & $\begin{array}{l}\text { ООО «Ивановское», } \\
\text { СПК СХА «Дружба», } \\
\text { ООО «Роща», } \\
\text { ООО «Долина,, } \\
\text { ООО «Колосок», } \\
\text { СХПК СХА } \\
\text { «Старожуковская», } \\
\text { СХПК СХА « Искра», } \\
\text { СХПК СХА «Нееловская», } \\
\text { ООО «Гусихинское», } \\
\text { СПК СХА «Алексеевская», } \\
\text { СХПК СХА «Содомская», } \\
\text { СПК СХА «Вязовская» }\end{array}$ \\
\hline Иmozo no 1-й гpynne: & 10 & 11 & 12 \\
\hline $\begin{array}{l}\text { 2. Неплатежеспособные } \\
\text { организации 1-й категории } \\
\text { (от } 3 \text { до } 12 \text { мес.) }\end{array}$ & $\begin{array}{l}\text { СПК СХА «Алексеевская», } \\
\text { СХПК СХА «Содомская», } \\
\text { СПК СХА «Вязовская», } \\
\text { ООО «Агро-Нива» }\end{array}$ & $\begin{array}{l}\text { СПК СХА «Вязовская», } \\
\text { ООО «Агро-Нива», } \\
\text { ООО «Гусихинское» }\end{array}$ & $\begin{array}{l}\text { ООО «Снежное», } \\
\text { ООО «Агро-Нива», } \\
\text { МУП «БК птицефабрика», } \\
\text { ЗАО ПЗ «Липовское» }\end{array}$ \\
\hline Итого по 2-й групnе: & 4 & 3 & 4 \\
\hline $\begin{array}{l}\text { 3. Неплатежеспособные } \\
\text { организации 2-й категории } \\
\text { (>12 мес.) }\end{array}$ & $\begin{array}{l}\text { МУП «БК птицефабрика», } \\
\text { ЗАО ПЗ «Липовское», } \\
\text { ООО «Кудашевский КЗ» }\end{array}$ & $\begin{array}{l}\text { МУП «БК птицефабрика», } \\
\text { ЗАО ПЗ «Липовское», } \\
\text { ООО «Кудашевский КЗ» }\end{array}$ & $\begin{array}{c}- \\
- \\
\text { ООО «Кудашевский КЗ» }\end{array}$ \\
\hline Итого по 3-й гpynne: & 3 & 3 & 1 \\
\hline Всего по району: & 17 & 17 & 17 \\
\hline
\end{tabular}

Источник: авторская разработка

Source: Authoring 


\section{Таблица 3}

Группировка сельскохозяйственных предприятий Базарно-Карабулакского района по степени платежеспособности по текущим обязательствам

Table 3

Grouping of agricultural enterprises of the Bazarno-Karabulakskii district according to the degree of solvency by current liabilities

\begin{tabular}{|c|c|c|c|c|c|c|}
\hline $\begin{array}{c}\text { Группы предприятий } \\
\text { по степени } \\
\text { платежеспособности }\end{array}$ & $\begin{array}{l}\text { Количество } \\
\text { предприятий }\end{array}$ & $\begin{array}{c}\text { Степень } \\
\text { платежеспособности } \\
\text { по текущим } \\
\text { обязательствам (Y) }\end{array}$ & $\begin{array}{l}\text { Окупаемость } \\
\text { затрат, \% }\left(x_{1}\right)\end{array}$ & $\begin{array}{c}\text { Удельный вес } \\
\text { заемного } \\
\text { капитала, \% } \\
\left(x_{2}\right) \\
\end{array}$ & $\begin{array}{c}\text { Доля } \\
\text { оборотного } \\
\text { капитала, \% } \\
\left(x_{3}\right) \\
\end{array}$ & $\begin{array}{c}\text { Уровень } \\
\text { государственной } \\
\text { поддержки, } \\
\text { тыс. руб. }\left(x_{4}\right) \\
\end{array}$ \\
\hline $\begin{array}{l}\text { 1. Платежеспособные } \\
\text { организации } \\
\text { (до 3-х мес.) }\end{array}$ & 12 & 1,358 & 127,2 & 9,1 & 50,7 & 2340 \\
\hline $\begin{array}{l}\text { 2. Неплатежеспособные } \\
\text { организации первой } \\
\text { категории } \\
\text { (от } 3 \text { до } 12 \text { мес.) }\end{array}$ & 4 & 5,959 & 115,8 & 70,3 & 32,6 & 1447 \\
\hline $\begin{array}{l}\text { 3. Неплатежеспособные } \\
\text { организации второй } \\
\text { категории (>12 мес.) }\end{array}$ & 1 & 24,865 & 62,9 & 99,7 & 100 & 322 \\
\hline Всего по району: & 17 & 2,877 & 120,7 & 28,8 & 49,4 & 2011 \\
\hline
\end{tabular}

Источник: авторская разработка

Source: Authoring

\section{Таблица 4}

Теоретические (нормативные) значения степени платежеспособности по текущим обязательствам сельскохозяйственных предприятий Базарно-Карабулакского района

\section{Table 4}

Theoretical (regulatory) values of solvency by current liabilities of agricultural enterprises of the Bazarno-Karabulakskii district

\begin{tabular}{|c|c|c|c|}
\hline Наблюдение & Фактические значения & Предсказанное $Y$ & Остатки \\
\hline \multicolumn{4}{|c|}{ Имеются неиспользованные резервы } \\
\hline МУП «БК ПФ» & 5,704 & 4,088 & 1,616 \\
\hline ООО «Долина» & 0,786 & 0,347 & 0,439 \\
\hline ООО «Ивановское» & 0 & 1,031 & $-1,031$ \\
\hline ООО «Колосок» & 0,962 & 0,922 & 0,04 \\
\hline ООО «Кудашевский КЗ» & 24,865 & 18,593 & 6,272 \\
\hline ООО «Снежное» & 3,211 & 1,777 & 1,434 \\
\hline СПК СХА «Вязовская» & 2,887 & 1,4 & 1,487 \\
\hline СХПК СХА «Содомская» & 2,524 & 1,031 & 1,493 \\
\hline \multicolumn{4}{|c|}{ Исчерпьвающе используют имеющиеся резервы } \\
\hline ЗАО ПЗ «Липовское» & 11,222 & 13,692 & $-2,47$ \\
\hline ООО «Агро-Нива» & 3,699 & 8,434 & $-4,735$ \\
\hline ООО «Гусихинское» & 2,816 & 3,572 & $-0,756$ \\
\hline OOO «Роща» & 0,727 & 1,127 & $-0,4$ \\
\hline СПК СХА «Алексеевская» & 1,32 & 2,001 & $-0,681$ \\
\hline СПК СХА «Дружба» & 0,038 & 0,662 & $-0,624$ \\
\hline СХПК СХА «Искра» & 1,284 & 2,466 & $-1,182$ \\
\hline СХПК СХА «Нееловская» & 1,958 & 2,043 & $-0,085$ \\
\hline СХПК СХА «Ст. Жуковская» & 0,994 & 3,81 & $-0,816$ \\
\hline
\end{tabular}

Источник: авторская разработка

Source: Authoring 


\section{Рисунок 1}

Структура баланса сельскохозяйственных предприятий Базарно-Карабулакского района Саратовской области (2012-2014 гг.)

\section{Figure 1}

The balance sheet structure of agricultural enterprises of the Bazarno-Karabulakskii district of the Saratov oblast, 2012-2014

\begin{tabular}{|l|l|}
\hline \multirow{2}{*}{$\mathrm{BA}-55,7 \%$} & $\mathrm{CK}-77,1 \%$ \\
\hline \multirow{2}{*}{$\mathrm{OA}-44,3 \%$} & \multicolumn{2}{|}{ ДК $-6 \%$} \\
& КК $-16,9 \%$ \\
\hline
\end{tabular}

2012

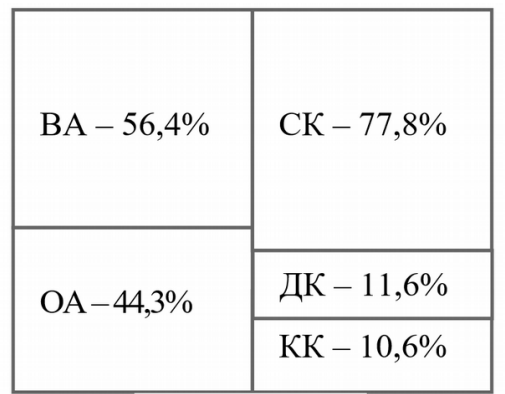

2013

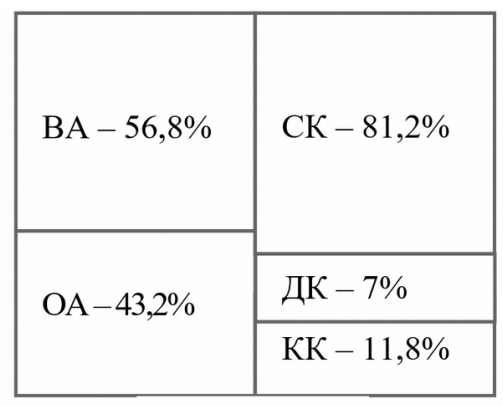

2014

Примечание. ВА - внеоборотные активы, ОА - оборотные активы, СК - собственный капитал, ДК - долгосрочный капитал, КК - краткосрочный капитал.

Источник: данные баланса сельскохозяйственных предприятий Базарно-Карабулакского района

Source: Balance sheet data of agricultural enterprises of the Bazarno-Karabulakskii district

\section{Рисунок 2}

Динамика показателей согласованности сроков получения и использования финансовых ресурсов в сельскохозяйственных предприятиях Базарно-Карабулакского района Саратовской области в 2012-2014 гг.

Figure 2

Changes in the finance source time and use consistency indicators of agricultural enterprises, the Bazarno-Karabulakskii district of the Saratov oblast, 2012-2014

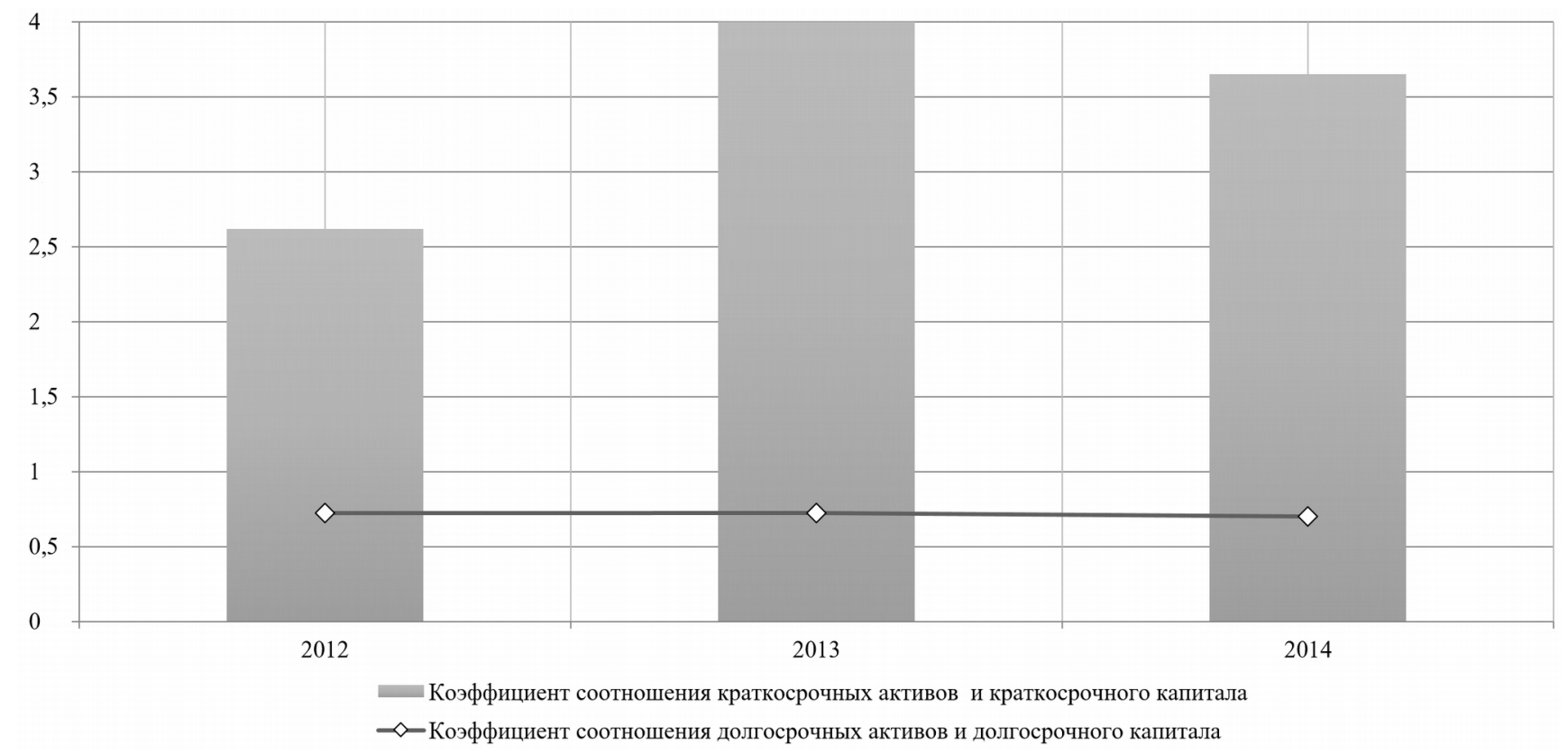

Источник: авторская разработка

Source: Authoring 


\section{Рисунок 3}

Степень платежеспособности по текущим обязательствам сельскохозяйственных предприятий Базарно-Карабулакского района, мес.

\section{Figure 3}

Solvency degree by current liabilities of agricultural enterprises of the Bazarno-Karabulakskii district, month

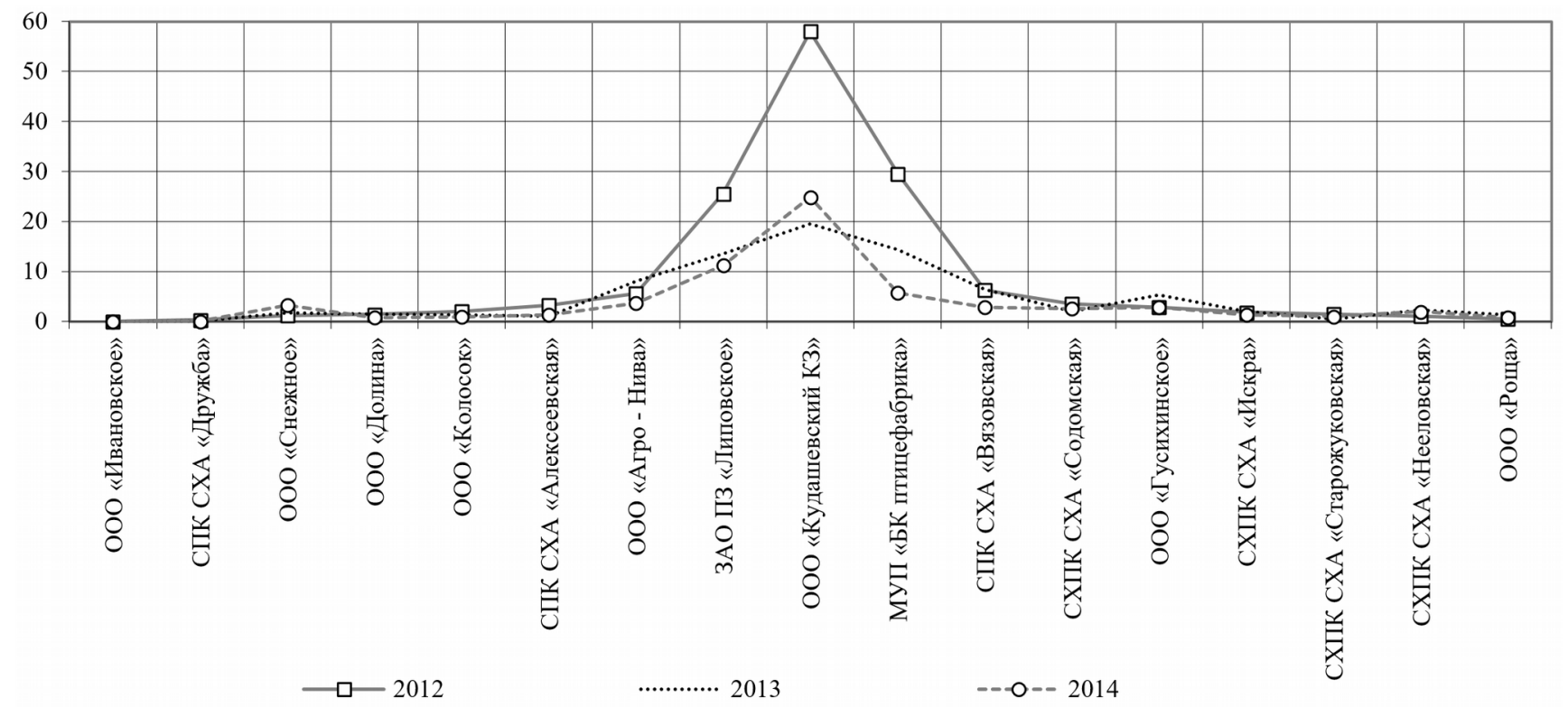

Источник: составлено авторами

Source: Authoring

\section{Список литературы}

1. Коновалов В., Коновалова T. Предпосылки и факторы устойчивого развития агропромышленного комплекса // Экономика сельского хозяйства России. 2014. № 12. С. $2-7$.

2. Романенко И., Сиптии С. Проблема эффективности и устойчивости развития сельского хозяйства в регионах Российской Федерации // Экономика сельского хозяйства России. 2015. № 2. С. 6-12.

3. Фефелова Н.П., Шарикова И.В., Говорунова Т.В., Дмитриева О.В. Современное состояние и оценка кредитования сельскохозяйственных предприятий АПК Саратовской области // Аграрный научный журнал. 2015. № 9. С. 95-100.

4. Воронченко T.B. Оценка перспектив деятельности предприятия на основе анализа его текущего финансового состояния // Ученые записки Российской Академии предпринимательства. 2008. № XV. C. $101-122$.

5. Манушин Д.В. Совершенствование сущности, видов и других аспектов анализа финансового состояния организаций // Актуальные проблемы экономики и права. 2009. № 1. С. 70-75.

6. Патласов О.Ю., Васина Н.В. Модели оценки финансового состояния для целей анализа кредитоспособности // Экономика сельскохозяйственных и перерабатывающих предприятий. 2008. № 12. С. $85-90$.

7. Симоненко Л.Г. Роль анализа структуры и движения капитала в оценке финансового состояния хозяйствующих субъектов // Научно-технические ведомости Санкт-Петербургского государственного политехнического университета. Экономические науки. 2006. № 5-2. С. 181-186.

8. Бариленко В., Луночкина E. Определение системы показателей анализа финансового состояния в концепции жизненного цикла организации (ЖЦО) // РИСК: Ресурсы, информация, снабжение, конкуренция. 2010. № 4. С. 432-436. 
9. Бобрышев А.Н., Ельчанинова О.В., Костюкова Е.И. Совершенствование методических подходов к анализу финансового состояния сельскохозяйственных организаций // Экономика сельскохозяйственных и перерабатывающих предприятий. 2009. № 11. С. 65-70.

10. Абросимова А.С., Юрханян К.А. Бухгалтерский баланс и использование результатов его анализа для оценки финансового состояния предприятия // Наука и знание. Краснодар: ФГБУ «Российское энергетическое агентство»; Минэнерго России; Краснодарский ЦНТИ - филиал ФГБУ «РЭА Минэнерго России, 2014. С. 27-32.

11. Жуковская С.Л., Оборин М.С. О некоторых особенностях проведения анализа активов предприятия // Известия Иркутской государственной экономической академии. 2014. № 1. С. 40-45.

12. Комельчик С.Л. Концептуальный подход к анализу состояния и динамики финансовых ресурсов организации // Экономика и управление. 2009. № 2/5. С. 90-94.

13. Козырева С.М., Колчерина В.В. Современные инструменты финансового менеджмента: золотое правило финансирования // Актуальные вопросы экономических наук. 2013. № 29-2. С. 130-136.

14. Манушин Д.В. Принципы, этапы и функции анализа финансового состояния организаций // Актуальные проблемы экономики и права. 2009. № 3. С. 53-59.

15. Волосевич Н.В. Методические подходы в оценке платежеспособности коммерческих организаций // Теория и практика общественного развития. 2014. № 16. С. 98-102.

16. Швеиова Н.К. Развитие методики анализа финансовой устойчивости предприятия // Современные проблемы науки и образования. 2014. № 4. C. 409. URL: https://science-education.ru/ru/article/view? $\mathrm{id}=14199$.

17. Шарикова И.В., Шариков А.В., Самитина С.А. Диагностика банкротства сельскохозяйственных предприятий. Саратов: Саратовский государственный аграрный университет им. Н.И. Вавилова, 2009. 84 с.

18. Алексеев А.А. Оценка финансового состояния предприятия с помощью методов многомерного статистического анализа на примере Калужской области // Телекоммуникации. 2007. № 9. С. 41-46.

19. Высоикая T.B. Построение статистических моделей диагностики кризисного состояния предприятий агропромышленного комплекса Карачаево-Черкесской республики // Вестник Астраханского государственного технического университета. Сер. Экономика. 2013. № 1. С. 119-125.

20. Корнев В.M. Диагностика финансового состояния сельскохозяйственных организаций региона с применением многомерного статистического анализа // Вестник Самарского государственного экономического университета. 2014. № 7. С. 124-127.

\section{Информация о конфликте интересов}

Мы, авторы данной статьи, со всей ответственностью заявляем о частичном и полном отсутствии фактического или потенциального конфликта интересов с какой бы то ни было третьей стороной, который может возникнуть вследствие публикации данной статьи. Настоящее заявление относится к проведению научной работы, сбору и обработке данных, написанию и подготовке статьи, принятию решения о публикации рукописи. 
ISSN 2311-8733 (Online)

ISSN 2073-1477 (Print)

Agro-Industrial Complex

\title{
THE FINANCIAL STATUS OF AGRICULTURAL ENTERPRISES: PROBLEMS, TRENDS, PERSPECTIVES: A REGIONAL ASPECT
}

\section{Irina V. SHARIKOVA ${ }^{\mathrm{a}, \bullet}$, Artem V. SHARIKOV ${ }^{\mathrm{b}}$, Tat'yana V. GOVORUNOVA ${ }^{\mathrm{c}}$, Natal'ya P. FRFRLOVA}

\author{
a Saratov State Agrarian University named after N.I. Vavilov, Saratov, Russian Federation \\ ivcharikova@yandex.ru \\ ${ }^{\mathrm{b}}$ Saratov State Agrarian University named after N.I. Vavilov, Saratov, Russian Federation \\ ooo_br@mail.ru \\ c Saratov State Agrarian University named after N.I. Vavilov, Saratov, Russian Federation \\ govorunovatv@mail.ru \\ d Saratov State Agrarian University named after N.I. Vavilov, Saratov, Russian Federation \\ fefelovanp@mail.ru \\ - Corresponding author
}

\section{Article history:}

Received 7 July 2016

Received in revised form

25 July 2016

Accepted 9 August 2016

Available online 15 May 2017

JEL classification: D22, G17, P47, R15, R51

https://doi.org/10.24891/re.15.5.869

Keywords: solvency, current liabilities, sustainability, golden rule, grouping

\begin{abstract}
Subject The article examines the financial status and the financial sustainability of the enterprises of agrarian sector of the Russian economy.

Objectives The article aims to study the problems of financial condition and solvency of agricultural enterprises, and assess their role in ensuring financial stability in the region.

Methods For the study, we used economic and statistical methods, grouping, and regression modeling.

Results Analyzing the financial condition of the agricultural enterprises of one of the districts of the Saratov oblast, we have assessed the indicators of variation and solvency distribution type, and we substantiate and propose a regression model of dependence of solvency on basic production factors. Conclusions In the Saratov oblast, there are administrative areas of crisis or precarious financial condition. However, during the studied period, there were certain positive changes in the composition and structure of their balance sheets. This has strengthened the financial sustainability of agricultural enterprises, changing their financial condition from crisis to unsustainable.
\end{abstract}

(C) Publishing house FINANCE and CREDIT, 2016

\section{References}

1. Konovalov V., Konovalova T. [Assumptions and factors of sustainable development of agro-industrial complex]. Ekonomika sel'skogo khozyaistva Rossii = Economics of Agriculture of Russia, 2014, no. 12, pp. 2-7. (In Russ.)

2. Romanenko I., Siptits S. [The issue of effectiveness and sustainability of agricultural development of the regions of the Russian Federation]. Ekonomika sel'skogo khozyaistva Rossii = Economics of Agriculture of Russia, 2015, no. 2, pp. 6-12. (In Russ.)

3. Fefelova N.P., Sharikova I.V., Govorunova T.V., Dmitrieva O.V. [Current status and the credit assessment of agricultural enterprises of the agrarian and industrial complex of the Saratov oblast]. Agrarnyi nauchnyi zhurnal = Agrarian Scientific Journal, 2015, no. 9, pp. 95-100. (In Russ.)

4. Voronchenko T.V. [Estimation of prospects of the enterprise on the basis of an analysis of its current financial status]. Uchenye zapiski Rossiiskoi Akademii predprinimatel'stva $=$ Scientific Notes of Russian Academy of Entrepreneurship, 2008, no. XV, pp. 101-122. (In Russ.)

5. Manushin D.V. [Improvement of the entity, types, and other aspects of the analysis of the financial condition of organizations]. Aktual'nye problemy ekonomiki i prava $=$ Actual Problems of Economics and Law, 2009, no. 1, pp. 70-75. (In Russ.)

6. Patlasov O.Yu., Vasina N.V. [A financial condition assessment model for creditworthiness analysis]. Ekonomika sel'skokhozyaistvennykh i pererabatyvayushchikh predpriyatii $=$ Economy of Agricultural and Processing Enterprises, 2008, no. 12, pp. 85-90. (In Russ.)

7. Simonenoko L.G. [The role of analysis of the structure and movement of capital within the assessment of the financial condition of business entities]. Nauchno-tekhnicheskie vedomosti Sankt-Peterburgskogo 
gosudarstvennogo politekhnicheskogo universiteta. Ekonomicheskie nauki $=$ St. Petersburg State Polytechnic University Journal. Economics, 2006, no. 5-2, pp. 181-186. (In Russ.)

8. Barilenko V., Lunochkina E. [Defining a system of indicators of financial analysis of the enterprise life cycle (ELC)]. RISK: Resursy, informatsiya, snabzhenie, konkurentsiya = RISK: Resources, Information, Supply, Competition, 2010, no. 4, pp. 432-436. (In Russ.)

9. Bobryshev A.N., El'chaninova O.V., Kostyukova E.I. [Improving methodological approaches to the analysis of a financial condition of agricultural organizations]. Ekonomika sel'skokhozyaistvennykh i pererabatyvayushchikh predpriyatii = Economy of Agricultural and Processing Enterprises, 2009, no. 11, pp. 65-70. (In Russ.)

10. Abrosimova A.S., Yurkhanyan K.A. Bukhgalterskii balans $i$ ispol'zovanie rezul'tatov ego analiza dlya otsenki finansovogo sostoyaniya predpriyatiya. V kn.: Nauka i znanie [Balance sheet and the use of the results of its analysis to assess the financial condition of the enterprise. In: Science and knowledge]. Krasnodar, Rossiiskoe energeticheskoe agentstvo Minenergo Rossii Krasnodarskii TsNTI - Branch of REA Minenergo Rossii Publ., 2014, pp. 27-32.

11. Zhukovskaya S.L., Oborin M.S. [Some of the features of analysis of the company's assets]. Izvestiya Irkutskoi gosudarstvennoi ekonomicheskoi akademii = Izvestiya of Irkutsk State Academy of Economics, 2014, no. 1, pp. 40-45. (In Russ.)

12. Komel'chik S.L. [A conceptual approach to the analysis of the status and trends of financial resources of the organization]. Ekonomika $i$ upravlenie = Economics and Management, 2009, no. 2/5, pp. 90-94. (In Russ.)

13. Kozyreva S.M., Kolcherina V.V. [Modern financial management tools: the golden rule of financing]. Aktual'nye voprosy ekonomicheskikh nauk, 2013, no. 29-2, pp. 130-136. (In Russ.)

14. Manushin D.V. [Principles, milestones, and the financial analysis functions of organizations]. Aktual'nye problemy ekonomiki i prava = Actual Problems of Economics and Law, 2009, no. 3, pp. 53-59. (In Russ.)

15. Volosevich N.V. [Methodological approaches in the assessment of the solvency of commercial organizations]. Teoriya $i$ praktika obshchestvennogo razvitiya $=$ Theory and Practice of Social Development, 2014, no. 16, pp. 98-102. (In Russ.)

16. Shvetsova N.K. [Development of methods of analysis of the enterprise financial stability]. Sovremennye problemy nauki $i$ obrazovaniya = Modern Problems of Science and Education, 2014, no. 4, pp. 409. (In Russ.). Available at: https://science-education.ru/ru/article/view?id=14199.

17. Sharikova I.V., Sharikov A.V., Samitina S.A. Diagnostika bankrotstva sel'skokhozyaistvennykh predpriyatii [Diagnosis of bankruptcy of agricultural enterprises]. Saratov, Saratov State Vavilov Agrarian University Publ., 2009, 84 p.

18. Alekseev A.A. [Evaluation of the financial condition of the enterprise by using the methods of multivariate statistical analysis: the Kaluga oblast case study]. Telekommunikatsii = Telecommunications, 2007, no. 9, pp. 41-46. (In Russ.)

19. Vysotskaya T.V. [Building the statistical models of crisis diagnosis of the agribusiness of the KarachayCherkess Republic]. Vestnik Astrakhanskogo gosudarstvennogo tekhnicheskogo universiteta. Ser. Ekonomika = Vestnik of Astrakhan State Technical University. Ser. Economics, 2013, no. 1, pp. 119-125. (In Russ.)

20. Kornev V.M. [Financial diagnostics of agricultural organizations of the region using a multivariate statistical analysis]. Vestnik Samarskogo gosudarstvennogo ekonomicheskogo universiteta $=$ Vestnik of Samara State University of Economics, 2014, no. 7, pp. 124-127. (In Russ.)

\section{Conflict-of-interest notification}

We, the authors of this article, bindingly and explicitly declare of the partial and total lack of actual or potential conflict of interest with any other third party whatsoever, which may arise as a result of the publication of this article. This statement relates to the study, data collection and interpretation, writing and preparation of the article, and the decision to submit the manuscript for publication. 